Ewa Bogacz-Wojtanowska

Uniwersytet Jagielloński w Krakowie e-mail: ewa.bogacz-wojtanowska@uj.edu.pl

Sylwia Wrona

Uniwersytet Jagielloński w Krakowie e-mail: sylwia.wrona@doctoral.uj.edu.pl

\title{
ZJAWISKO FEMINIZACJI ORGANIZACJI POŻYTKU PUBLICZNEGO W POLSCE DZIAŁAJĄCYCH NA RZECZ KOBIET
}

\begin{abstract}
The Feminization of Non-governmental Organizations. Non-governmental Organizations in Poland Working for Women's Cause
\end{abstract}

Study results presented in this article are trying to identify the scale of activity among Polish women in non-governmental organizations, that were recognized as working for women's cause. In order to accomplish that goal, evaluation of women's share in non-governmental organization's management was performed, as well as analysis of statutory objectives, its implementation and areas of gratuitous actions.

Keywords: feminization, women non-governmental organizations, women's activity

\section{Streszczenie}

Zaprezentowane w artykule badania starają się uchwycić skalę aktywności kobiet w polskich organizacjach pożytku publicznego, które zostały zidentyfikowane jako działające na rzecz kobiet. W tym celu dokonano oceny udziału kobiet we władzach organizacyjnych, a także poddano analizie cele statutowe i sposoby ich realizacji oraz sfery nieodpłatnych działan.

Słowa kluczowe: feminizacja, kobiece organizacje pozarządowe, aktywność kobiet

\section{Wstęp}

Aktywność i praca kobiet w organizacjach pozarządowych rzadko jest poddawana systematycznym badaniom w Polsce i na świecie. Brakuje precyzyjnych statystyk prezentujących sytuację kobiet w organizacjach trzeciego sektora, 
w szczególności udział kobiet we władzach organizacji oraz specyfikę i zakres formułowanych misji organizacyjnych i realizowanych celów w zakresie potrzeb i praw kobiet. Słabo rozpoznane są także uwarunkowania rozwoju organizacji kobiecych na świecie, w szczególności polityczno-prawne i kulturowe.

Stąd istotne wydaje się rozpoznanie, jak wygląda sytuacja kobiet w polskich organizacjach pozarządowych w zakresie zarówno ich reprezentacji we władzach organizacji, jak i realizacji misji organizacyjnych. W szczególności interesujące jest to, jak w tej sferze wypadają organizacje kobiece, czyli takie, które prowadzą swoje działania na rzecz kobiet. W rezultacie celem naszego opracowania jest prezentacja i ocena udziału kobiet we władzach wybranych polskich organizacji pozarządowych oraz rozpoznanie ich aktywności w ramach założonych celów i obszarów działań. Ocenie poddano organizacje pożytku publicznego (OPP), których cele statutowe są związane szeroko z realizacją praw i usług skierowanych do kobiet. Przez feminizację organizacji pozarządowych rozumiemy zarówno stopniowe zwiększanie udziału kobiet we władzach organizacji, w pracach wolontaryjnych i zawodowych, jak i upowszechnianie się w organizacjach etosu pracy menadżerskiej kobiet [Fondas, 1997] oraz tzw. kobiecych kultur organizacyjnych. Analogicznie, używając terminu feminizacja trzeciego sektora, rozumiemy ją jako stopniowe dominowanie przez kobiety działalności trzeciego sektora.

\section{Badania i statystyki krajowe i międzynarodowe}

Pierwsze polskie badania sytuacji dotyczącej aktywności i zatrudnienia kobiet w trzecim sektorze zrealizowano w 2005 roku. Wykazały one, że kobiety w nim pracujące cieszyły się z pozytywnej atmosfery, możliwości samodoskonalenia i rozwoju zawodowego oraz tolerancyjnego nastawienia do macierzyństwa [Wysocka, 2009]. Badanie nie ujawniło praktyk dyskryminacyjnych w stosunku do kobiet w trzecim sektorze i obaw przed utratą pracy, raczej świadomość i poczucie odpowiedzialności za organizacje, w których pracują. Jednocześnie badania dowiodły, że istnieją także pewne cechy pracy w organizacjach pozarządowych, mogące sprzyjać podniesieniu aktywności i zatrudnialności kobiet, takie jak: wykorzystywanie i rozszerzanie kwalifikacji kobiet, mało formalne stosunki w pracy, zatrudnienie typu flexicurity, zwłaszcza elastyczność w zakresie czasu pracy [Bogacz-Wojtanowska, Rymsza, 2009]. Na tle sektorów publicznego i prywatnego trzeci sektor dla kobiet w nim zatrudnionych był najbardziej przyjazny, w przeciwieństwie do zbyt konkurencyjnego biznesu czy zbiurokratyzowanych i pełnych rutyny organizacji publicznych [Wysocka, 2009]. Jednocześnie badania dowodziły, że brakuje kobietom stabilności zatrudnienia i wyższych pensji, które do dziś są raczej rzadkie w trzecim sektorze. Inne badania prowadziły do wniosków, że kobiety, decydując się na działanie w organizacjach pozarządowych, pragną realnych zmian zmierzających do poprawy obecnej sytuacji kobiet, których samorealizacja z różnych przyczyn jest utrudniona. Innymi motywacjami 
są realizacja potrzeb kobiet z zakresu usług publicznych i upowszechnianie idei równouprawnienia [Domaradzka, 2009].

Bardziej współczesne badania pokazują przede wszystkim, że w ujęciu ilościowym kobiety nieco częściej angażują się w działania społeczne (37\% kobiet i 31\% mężczyzn zadeklarowało swoją aktywność społeczną w 2013 roku), a także rzadziej deklarują postawy aspołeczne i brak zaufania do innych [Zaangażowanie społeczne, 2014]. Feminizacja trzeciego sektora w Polsce, jak dowodzą badania Stowarzyszenia Klon/Jawor z 2012 roku, dotyczy pracowników i wolontariuszy, nie dotyczy z kolei członków organizacji i władz (zarządów i rad) [Adamiak, Herbst, Przewłocka, 2012], co wyraźnie wskazywało na podział ról w polskim sektorze pomiędzy kobiety i mężczyzn. Te same badania pokazują, że zarząd przeciętnej organizacji pozarządowej liczy pięciu członków, przy czym na cztery kobiety $\mathrm{w}$ organizacjach korporacyjnych $\mathrm{i}$ we władzach organizacji przypada sześciu mężczyzn, w szczególności gdy uwzględni się w statystykach silne zmaskulinizowane w Polsce organizacje sportowe. Gdy jednak z analiz je wykluczymy (choć oczywiście trudno, bo stanowią istotną siłę w trzecim sektorze), to sytuacja staje się niemal proporcjonalna. Ową proporcjonalność natomiast wykazały nowsze badania Stowarzyszenia Klon/Jawor z 2015 roku, w których przeciętna liczba osób w zarządzie pozostała taka sama, jednak odsetek kobiet w nim zasiadających wzrósł do 47\% [Adamiak, Charycka, Gumkowska, 2016]. Jednakże tym, co niewątpliwie charakteryzuje polski trzeci sektor, jest liczebna przewaga pracownic i wolontariuszek [Adamiak, Herbst, Przewłocka, 2012]. Co ciekawe, za zwiększeniem udziału kobiet na stanowiskach kierowniczych w organizacjach pozarządowych opowiada się także 47\% Polaków [CBOS, 2013].

M. Borowska, na podstawie prowadzonych ilościowych badań, wskazuje na kilka istotnych faktów, dotyczących sytuacji kobiet $w$ organizacjach pozarządowych:

- w trzecim sektorze istnieją obszary zdominowane przez kobiety, co wiąże się z segregacją poziomą - są to ochrona zdrowia, edukacja i pomoc społeczna;

- „szklane zjawiska” z rynku pracy występują także w organizacjach pozarządowych - częstsze awansowanie mężczyzn w sfeminizowanych organizacjach (tzw. „szklane ruchome schody”) czy „lepka podłoga”;

- nie mamy dziś raczej do czynienia ze „,szklanym sufitem” w polskim trzecim sektorze, gdyż skład władz zbliża się do parytetu [Borowska, b.d.].

Feminizacja zarządów organizacji zajmujących się trzema wymienionymi obszarami [Adamiak, Charycka, Gumkowska, 2016] może być związana z systemami wartości deklarowanymi przez kobiety i mężczyzn. Dla kobiet największe znaczenie mają zdrowie i wykształcenie, mężczyźni podkreślają wagę dobrobytu, przyjaźni i patriotyzmu [CBOS, 2013].

Warto podkreślić, że polskie organizacje pozarządowe wpisują się także w pewien sposób w obszar działań ruchów feministycznych w Polsce. W ramach teorii polskiego feminizmu S. Mendes [2007] wyróżnia trzy nurty: radykalny, kulturowy oraz instytucjonalny. Do nurtu radykalnego zostały włączone anarchofeministki oraz działania kontrkulturowe. W ramach nurtu kulturalnego funkcjonują np. ośrodki badawcze oraz stowarzyszenia i grupy nieformalne krytykujące 
kulturę z perspektywy feministycznej, a także grupy artystyczne, teologiczne i ekologiczne czerpiące z tradycji feministycznej. Ostatni nurt, instytucjonalny,

odnosi się do różnego rodzaju organizacji pozarządowych nieposiadających zaplecza społecznego, który jednak poprzez fakt posiadania zasobów finansowych oraz kompetencji odgrywa znaczącą rolę. Organizacje te zajmują się najczęściej bezpośrednią pomocą kobietom lub lobbingiem. W swoich działaniach jedynie w marginalnym stopniu mobilizują członkinie ruchu feministycznego [Mendes, 2007, s. 468].

Warto zauważyć, że feminizacja trzeciego sektora jest zjawiskiem, które występuje w wielu krajach na świecie, choć zwykle wskaźniki nie są tak skrajne, jak w powszechnym mniemaniu się uważa. Niektórzy zwracają uwagę, że w krajach słabo rozwiniętych, tam gdzie zatrudnienie jest „na wagę złota”, w trzecim sektorze pracuje więcej mężczyzn. W patriarchalnych społeczeństwach $\mathrm{w}$ organizacjach pozarządowych przeważają mężczyźni [Sahasrabuddhe, 2013]. Szwedzki sektor pozarządowy jest sfeminizowany od końca XIX wieku, choć na początku tego okresu tworzyli go mężczyźni klasy średniej. Na przestrzeni stu lat został sfeminizowany nie tylko w sferze liczby kobiet, lecz także odejścia od patriarchalnej formuły funkcjonowania organizacji [Sköndalsinstitutet, Wijkström, 1995]. We Francji feminizacja jest obserwowana zarówno w sektorze publicznym, jak i pozarządowym, co jest związane $\mathrm{z}$ dwoma czynnikami: pierwszy to bardziej przyjazne rodzinom oba sektory, drugi - większe zainteresowanie mężczyzn korzyściami pracy w sektorze biznesowym. Dodatkowo sektor pozarządowy we w Francji stwarza większe możliwości pracy w niepełnym wymiarze, a także oferuje krótszy tydzień pracy [Lanfranchi, Narcy, 2013]. Z kolei w amerykańskim trzecim sektorze kobiety odgrywają istotną rolę, w szczególności w obszarze filantropii, zatrudnieniu i wolontariacie. Jak pisze E. Davidson, tradycyjna amerykańska filantropia została zbudowana na kobietach, które dzięki bogactwom swoich mężów nie tylko przez stulecia już przecież wspomagały biedniejszych, ale także budowały muzea czy uniwersytety [Davidson, b.d.]. Co ciekawe, badania amerykańskie pokazują, że same kobiety, a także społeczeństwo, często umniejszają kobiecą rolę i znaczenie w pracy wolontaryjnej i na rzecz trzeciego sektora oraz często nieintencjonalnie powielają tradycyjne role kobiet [Mannon, Petrzelka, 2006].

Równie interesujące jest to, jakie są przewidywania w kwestii aktywności i pracy kobiet w trzecim sektorze. Tutaj toczą się różne dyskusje. Niektórzy zwracają dziś uwagę na to, że tradycyjny trzeci sektor w Wielkiej Brytanii, Australii czy Kanadzie, oparty na filantropii, zmienia się w ostatnich latach, w szczególności w obszarach usług społecznych. Organizacje pozarządowe, charakteryzujące się kolektywnym działaniem, opartym na etyce, budujące zespoły, troszczące się o podopiecznych i pracowników, odwołujące się do społecznej sprawiedliwości, zmieniają się lub są „kolonizowane” przez technokratyczne rozwiązania, stały monitoring i pomiary wyników oraz skupienie na technicznych procesach realizacji celów [Baines, Charlesworth, Cunnigham, Dassinger, 2012]. Innymi słowy, organizacje pozarządowe zamieniają się w podmioty bardzo podobne do konkurencyjnych i zdeterminowanych na sukces organizacji biznesowych. Stają 
się bardziej „męskie” w swoich kulturach organizacyjnych, co badacze kojarzą z postępującą maskulinizacją sektora, wynikającą ze zmian na rynkach pracy, na których liczba zwalnianych mężczyzn, którzy „przesuwają” się w kierunku zawodów czy sektorów właśnie tradycyjnie ,zajętych” przez kobiety, rośnie. Kobiece przywództwo czy zarządzanie organizacją pozarządową, zdaniem niektórych autorów, jest skupione na pielęgnowaniu wartości, komunikacji międzyludzkiej oraz partycypacyjnym podejmowaniu decyzji [Vasavada, 2012]. Męskie - odwrotnie, co znacząco będzie zmieniać organizacje pozarządowe w przyszłości. Należy zauważyć, że narzędzia i metody zarządzania typowe dla przedsiębiorstw nie przedostają się zbyt spiesznie do praktyki trzeciego sektora w Polsce. Ciągle więcej chyba mamy klasycznych przywódców niż technicznych i sprawnych menadżerów, co oczywiście nie zawsze musi być dla organizacji korzystne, gdyż, jak dowodzą amerykańskie badania, organizacje pozarządowe są słabo zarządzane, a dobrze przewodzone [Morino, 2011], co skutkuje choćby kłopotami organizacji w obszarach finansów i oceny wyników działania. Kulturowe i społeczne uwarunkowania rozwoju sektora są także nieco inne. Wydaje się jednak, że zarówno „kobiece”, jak i „męskie” w stylach zarządzania organizacje pozarządowe znajdą swoje miejsce w trzecim sektorze.

Należy podkreślić także, że od lat 90 . XX wieku istniały programy i systemy dotacji przeznaczone na rozwój projektów i organizacji „,prokobiecych” w Polsce. Warto tutaj chociażby wspomnieć powstanie w 1996 roku Forum Współpracy Organizacji Pozarządowych, które to uruchomiło Krajowy Program Działań na rzecz Kobiet z szerokimi postulatami działań na rzecz poprawy sytuacji polskich kobiet. W 2003 roku Fundacja Ośka współtworzyła Program Wspierania Polskich Organizacji, Inicjatyw, Grup Kobiecych „Fundusz dla Kobiet”, którego celem było wzmocnienie potencjału kobiet i wsparcie rozwoju ich działalności politycznej [Drewniak, 2012]. Podobnie w pierwszej perspektywie finansowania z Unii Europejskiej, temat wzmacniania pozycji kobiet miał istotne znaczenie. Dziś jednak bardziej promuje się rodzinę czy godzenie obowiązków rodzinnych i zawodowych, a nie równouprawnienie. Co prawda, kwestia równouprawnienia została wpisana w tak zwane polityki horyzontalne UE, i Polska jest zobowiązana do ich stosowania. Zgodnie z Rozporządzeniem Parlamentu Europejskiego i Rady UE [2013], państwa członkowskie i Komisja Europejska zapewniają uwzględnianie i propagowanie równości mężczyzn i kobiet oraz punktu widzenia płci w trakcie przygotowywania i wdrażania programów, w tym w odniesieniu do monitorowania, sprawozdawczości i ewaluacji, oraz podejmowania działań w celu zapobiegania wszelkim formom dyskryminacji, m.in. ze względu na płeć. Pomimo tego, że kwestie równości kobiet i mężczyzn zapisano także w traktacie lizbońskim, to w praktyce działania organizacji pozarządowych sprowadza się tylko do deklaracji projektowych. Jak twierdzi M. Borowska [2012], większość polskich organizacji uznaje kwestie równościowe za „wyraz konieczności zachowania poprawności politycznej lub przykry obowiązek wynikający z prawa antydyskryminacyjnego", co nie oznacza jednocześnie niechęci do samej idei, raczej brak wiedzy o tym, jak te zasady równościowe i antydyskryminacyjne wdrożyć w życie organizacji. 


\section{Metodyka badań}

Dla poznania i oceny aktywności kobiet w organizacjach pożytku publicznego, których cele są zorientowane na realizację praw i usług skierowanych do kobiet, a także rozpoznania, jak przedstawia się udział kobiet we władzach organizacji, zastosowano metodę desk research (analiza dostępnych dokumentów organizacyjnych).

Założono, że udział kobiet we władzach organizacyjnych, rozumiany tutaj jako członkostwo w zarządzie oraz organie kontroli lub nadzoru, w tym rozróżnienie na obejmowane stanowisko, czyli przewodniczącego/ącej, prezesa/ski bądź członka/ ini, pozwoli rozpoznać, kto uczestniczy w podejmowaniu najważniejszych decyzji organizacyjnych. Identyfikacja celów statutowych i obszarów najważniejszych działań oraz sfer nieodpłatnych działań będzie podstawą do oceny typu i formy deklarowanych aktywności badanych organizacji w zakresie spraw związanych z problemami kobiet.

W związku z tym wskazano następujące główne pytania badawcze:

1. Jaki jest udział kobiet we władzach organizacyjnych organizacji pożytku publicznego działających na rzecz spraw kobiet?

2. Jakie są cele statutowe badanych organizacji pożytku publicznego i w jakiej mierze są one „kobiece”?

3. Jakie są sfery nieodpłatnych działań organizacji pożytku publicznego działających na rzecz kobiet?

Założono, że badanie obejmie tylko organizacje pożytku publicznego, gdyż muszą one publikować na stronach ministerstwa właściwego dla zabezpieczenia społecznego własne sprawozdania merytoryczne, co pozwala na pozyskanie przez badacza odpowiednich danych. Wybór organizacji pożytku publicznego został dokonany na podstawie następujących kryteriów:

- posiadanie statusu organizacji pożytku publicznego,

- pozyskanie w ramach $1 \%$ jakiejkolwiek kwoty zasilającej budżet organizacji,

- aktywność na rzecz kobiet.

Rozpoznanie, czy organizacja prowadzi działalność na rzecz kobiet, nastąpiło poprzez poszukiwanie kobiecych organizacji pozarządowych według słów-kluczy: „kobieta”, „kobiety” w nazwie organizacji. Analizowano w ten sposób wszystkie organizacje pożytku publicznego znajdujące się w bazie ministra ds. zabezpieczenia społecznego. Ostatecznie próbę badawczą stanowi 55 organizacji, które łącznie spełniają wszystkie kryteria. Analizie poddano sprawozdania merytoryczne 55 organizacji pożytku publicznego działających na rzecz kobiet.

W badaniach zastawano metodologię mieszaną, pozwalającą na uchwycenie zarówno ilościowego charakteru badań - w przypadku analizy władz organizacyjnych oraz sfery nieodpłatnych działań, jak i jakościowego - w przypadku analizy celów i sfer działalności organizacji.

W przypadku analizy ilościowej sporządzono bazę danych na podstawie zamieszczonych na stronie www.pozytek.gov.pl sprawozdań merytorycznych organizacji pożytku publicznego z 2015 roku. Analiza jakościowa materiału polegała 
na wielokrotnym czytaniu materiału badawczego (sprawozdań merytorycznych badanych organizacji), wraz ze stopniową kategoryzacją danych oraz ich porównywaniem w obrębie każdego pytania badawczego. Pozwoliło to na wprowadzenie pewnych uogólnień o charakterze eksplanacyjnym i ilustracyjnym, które nie roszczą sobie jednak praw do uniwersalności.

Analiza materiału badawczego dotyczyła treści następujących rubryk sprawozdania merytorycznego: skład organu zarządzającego organizacji (wypełniło 52 OPP, 48 wskazań stanowiska przewodniczącego/ej OPP), skład organu kontroli lub nadzoru organizacji (wypełniło 50 OPP, 39 wskazań stanowiska przewodniczącego/ej OPP), cele statutowe organizacji (wypełniło 18 OPP), sposób realizacji celów statutowych organizacji (wypełniło $18 \mathrm{OPP}$ ), opis działalności pożytku publicznego (wypełniło 52 OPP), sfera działalności pożytku publicznego (działalność nieodpłatna pożytku publicznego - wypełniło 55 OPP). Z powodu niepełnego uzupełniania sprawozdania merytorycznego zdecydowano się na uwzględnienie zapisów w formie zawierającej przedstawione rubryki, które były uzupełniane lub też nie przez organizacjel.

\section{Wyniki badań}

\section{I. Kobiety we władzach kobiecych organizacji pożytku publicznego}

W zakresie feminizacji władz badanych organizacji pożytku publicznego można zauważyć, że w zarządach badanych kobiecych organizacji pożytku publicznego ok. 95\% członków stanowią kobiety, zaś 5\% - mężczyźni (Rysunek 1). Średnia liczba osób zasiadająca w zarządach (członkowie i przewodniczący/a) badanych organizacji pożytku publicznego w 2015 roku to 3,7.

Stanowisko prezesa/prezeski zarządu analizowanych organizacji pożytku publicznego przypada w ok. 96\% kobietom, zaś w ok. 4\% mężczyznom (Rysunek 1). Warto zauważyć, że kobiety na stanowisku szefa zarządu w dużej mierze przewodzą kobietom, na co wskazuje udział kobiet w zarządach. Mężczyźni zarówno jako członkowie zarządu, jak i przewodniczący zarządu stanowią zdecydowaną mniejszość.

$\mathrm{W}$ organach kontroli lub nadzoru badanych organizacji pożytku publicznego zasiada nieznacznie większy odsetek mężczyzn niż w przypadku zarządu - ok. 7\%

${ }^{1}$ Decyzja o uwzględnieniu wszystkich występujących form sprawozdania naraziłaby wnioski z badań na nadinterpretację oraz wymusiłaby konieczność dodania kategorii (i tym samym celów i pytań badawczych), których rozpoznanie i interpretacja nie jest celem tego opracowania. Ponadto zmusiłaby do rozdziału i podziału, a następnie interpretacji pojęć używanych przez organizacje w sprawozdaniach, z tytułu używania i przyporządkowywania przez organizacje takich, a nie innych treści, w taki, a nie inny sposób. Dlatego też oddając prawo do nazywania i opisywania swojej działalności organizacjom, trzymano się sztywno wyznaczonych przez nie w sprawozdaniu ram. 
(Rysunek 2). Przewaga kobiet jest jednak zdecydowana, stanowią one średnio ok. 93\% członków organu kontroli. Średnia liczba osób zasiadająca w organach kontroli lub nadzoru (członkowie i przewodniczący/a) 50 badanych organizacji pożytku publicznego w 2015 roku to 2,2.

Zarząd

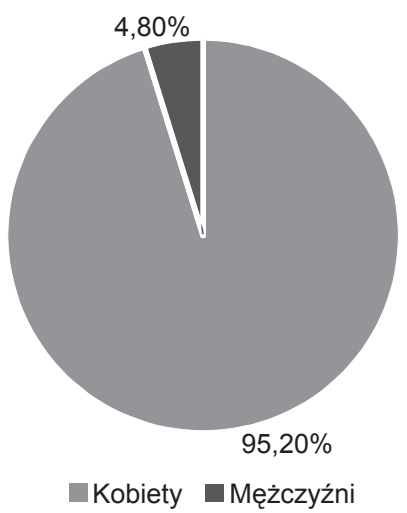

Prezes/ka zarządu

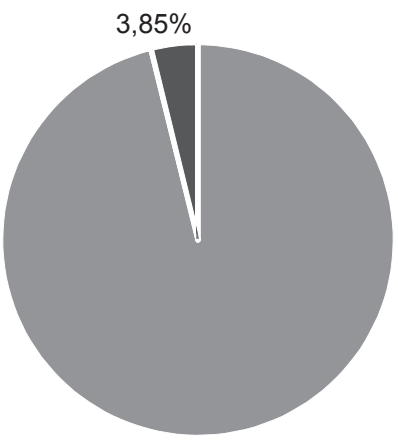

$96,15 \%$

Kobiety Mężczyźni

Rysunek 1. Średni udział kobiet i mężczyzn w zarządach i na stanowiskach prezesów badanych organizacji pożytku publicznego wyrażony w procentach

Źródło: opracowanie własne na podstawie kolejno 48 i 52 wskazań w wypełnionych sprawozdaniach merytorycznych za 2015 rok na 55 badanych organizacji pożytku publicznego.

Skład organu kontroli

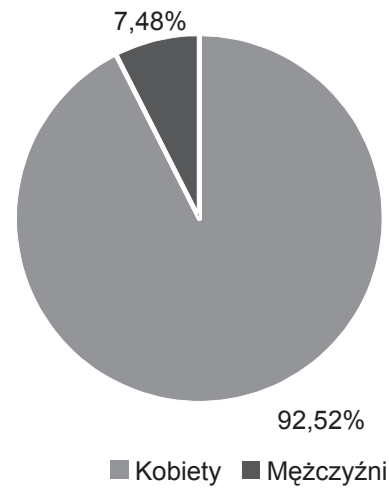

Przewodniczący organu kontroli

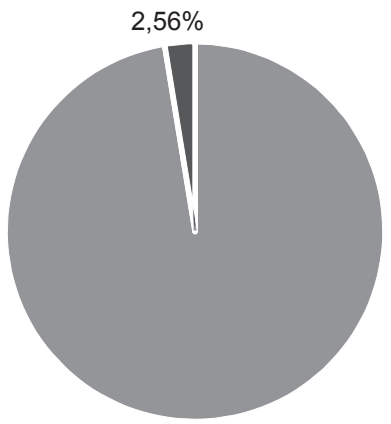

$97,44 \%$

Kobiety Mężczyźni

Rysunek 2. Średni udział kobiet i mężczyzn w organach kontroli lub nadzoru i na stanowiskach przewodniczących organów kontroli lub nadzoru badanych organizacji pożytku publicznego wyrażony w procentach

Źródło: opracowanie własne na podstawie 50 i 39 wskazań w wypełnionych sprawozdaniach merytorycznych za 2015 rok na 55 badanych organizacji pożytku publicznego. 
Podobnie jak w przypadku obejmowanych stanowisk prezesów i prezesek w zarządach badanych organizacji pożytku publicznego, stanowisko przewodniczącego/ej organu kontroli lub nadzoru zdecydowanie częściej obejmują kobiety. Średnio ok. 97\% przewodniczących to kobiety, ok. 3\% - mężczyźni (Rysunek 2).

\subsection{Cele statutowe kobiecych organizacji pożytku publicznego}

W przypadku badanych organizacji pożytku publicznego, które powstały z myślą o środowisku kobiecym, skupiając się na oczekiwaniach, potrzebach i problemach kobiet, zostały zidentyfikowane następujące grupy celów statutowych: prawa kobiet i realizacja ich praw, rozwój społeczno-ekonomiczny i integracja kobiet, pomoc społeczna, ochrona zdrowia, edukacja, kultura, sztuka i rekreacja, społeczeństwo obywatelskie.

Najważniejszą grupę stanowią te organizacje pożytku publicznego, które w swoich celach zakładają działania na rzecz ochrony praw człowieka, upowszechnianie i przestrzeganie zasad etyki zawodowej i sprawiedliwości ekonomicznej, a także zasad równego traktowania kobiet i mężczyzn we wszystkich sferach życia, tj. społecznej, politycznej, gospodarczej i prywatnej. Kładziony jest nacisk na popularyzację wiedzy o prawach i wolnościach człowieka, takich jak, ,prawo do przyjemności i ekspresji seksualnej kobiet, wraz z prawem do wyrażania swojej orientacji seksualnej, prawo do wyrażania swoich przekonań w formie werbalnej lub wizualnej bez jakiejkolwiek cenzury” oraz ,,prawo kobiet do opieki zdrowotnej, korzystania z dowolnych metod planowania rodziny i prawo do decydowania, kiedy i w jakich okolicznościach urodzić dziecko"². Podejmowane są działania zwiększające uczestnictwo kobiet w organach władzy. Badane organizacje przeciwdziałają dyskryminacji strukturalnej i prawnej oraz wykluczeniu społecznemu ze względu między innymi na ,wiek, niepełnosprawność, status społeczny i majątkowy, przekonania, rasę, narodowość i orientację seksualną oraz uprzednią karalność"’. Tym samym decydują się również na reprezentowanie i ochronę interesów członków organizacji oraz poszerzenie dostępu do informacji, poradnictwa i pomocy prawnej, finansowej i psychologicznej.

Kolejnym obszarem określania celów statutowych badanych organizacji pożytku publicznego jest szeroko rozumiany rozwój, w tym osobisty, uczestników i członków organizacji. Organizacje te kładą nacisk m.in. na rozwój „osobowości, edukacji i reaktywacji zawodowej, profilaktyki zdrowia oraz przedsiębiorczości i promocji aktywności w życiu publicznym"4. Mają one na celu przeciwdziałanie bezrobociu, promowanie zatrudnienia, a także podnoszenie statusu zawodowego i aktywizację zawodową kobiet. Ponadto wspierają integrację środowisk kobiecych, inicjatywy i twórczość kobiet.

\footnotetext{
${ }^{2}$ Cytat ze sprawozdania jednej z badanych OPP.

$3 \mathrm{JW}$.

${ }^{4} \mathrm{JW}$.
} 
Trzecim zidentyfikowanym przez nas obszarem definiowania celów statutowych badanych OPP są działania z zakresu pomocy społecznej, porządku i bezpieczeństwa, w szczególności przeciwdziałanie patologiom społecznym. Działania te koncentrują się między innymi na niesieniu ,pomocy osobom i rodzinom znajdującym się w kryzysie społecznym, zawodowym, rodzinnym, w szczególności ofiarom przemocy domowej, samotnym matkom, osobom bezrobotnym, osobom uzależnionym i współuzależnionym, dzieciom i młodzieży"5 oraz osobom poszkodowanym $\mathrm{w}$ wyniku przestępstwa i wykroczenia, poddanym wykluczeniu i krzywdzonym. Cele badanych OPP koncertują się także w tym obszarze na działalności charytatywnej.

Następnym obszarem realizacji celów, wskazywanym przez badane organizacje, jest propagowanie zdrowego trybu życia, a przede wszystkim profilaktyka, ochrona i promocja zdrowia, w szczególności „zdrowia psychicznego i prokreacyjnego oraz dostępu do edukacji seksualnej, rehabilitacji i zajęć sportowych"6. Wiele organizacji w swych celach skupia się na pomocy kobietom w procesie rozpoznawania między innymi chorób kobiecych oraz nowotworów, a następnie na opiece nad chorymi oraz oferowaniu wsparcia po przebytej chorobie. Ponadto udzielają pomocy placówkom medycznym i szpitalom, wspomagają programy leczenia i rozwój pielęgniarstwa, a także stwarzają i propagują warunki rozwoju polityki zdrowotnej państwa i władz lokalnych.

Istotne są także cele związane edukacją. Organizacje deklarują, że prowadzą szeroko zakrojoną edukację, między innymi w zakresie: dyskryminacji, polskiego i unijnego prawodawstwa i równouprawnienia, gender, historii kobiet i ruchu kobiecego, zdrowia i medycyny. Decydują się one na zorganizowanie działalności informacyjno-edukacyjnej, która ma na celu uświadomienie społeczeństwu problemów i potrzeb związanych z wymienionymi dziedzinami.

Kolejny zakładany przez badane organizacje obszar realizacji celów statutowych to prowadzenie działalności w zakresie kultury i sztuki (np. chrześcijańskiej), a także działalność rozrywkowa i wypoczynkowa. Część organizacji pożytku publicznego zajmuje się organizowaniem imprez okolicznościowych, wypoczynku dla dzieci i młodzieży „,w formie kolonii wypoczynkowych, zdrowotnych, zimowisk, wczasów rodzinnych i wycieczek" ". Wśród wymienianych przez badane organizacje celów statutowych znalazły się także działania z obszaru środowiska, ekologii i ochrony zwierząt, a także sprawowanie pieczy nad dziedzictwem przyrodniczym.

I wreszcie w kręgu zainteresowań badanych organizacji pożytku znalazły się kwestie związane z budowaniem społeczeństwa obywatelskiego i rozwijaniem dialogu społecznego, a także wspieraniem wspólnot i społeczności lokalnych. Organizacje te starają się pobudzać aktywność obywatelską, tworzyć warunki społecznej i politycznej aktywności kobiet, poprzez upowszechnianie równouprawnienia przyczyniać się do stanowienia sprawiedliwego i otwartego społeczeństwa

\footnotetext{
5 JW.

6 JW.

7 JW.
} 
obywatelskiego. Badane organizacje pożytku publicznego zwracają uwagę na skuteczne działania organizacji. Jednym z nich jest rozwijanie kontaktów i współpracy pomiędzy różnego typu środowiskami. Organizacje te pragną wymieniać doświadczenia i wiedzę zarówno z polskimi, jak i międzynarodowymi organizacjami pozarządowymi, a także instytucjami publicznymi i prywatnymi. Znajduje się tutaj także wspieranie rozwoju organizacji pozarządowych, wolontariat i upowszechnianie jego idei.

\subsection{Działania OPP na rzecz kobiet}

Zidentyfikowane obszary celów statutowych należy interpretować jako ważne dla członków badanych organizacji z perspektywy funkcjonowania i sukcesu organizacji. Ich realizacja jest jednak przede wszystkim uzależniona od sprawności i skuteczności działań i obranych metod wykonawczych. Organizacje pożytku publicznego realizują swoje cele statutowe głównie poprzez odpłatną i nieodpłatną działalność pożytku publicznego, chociaż pierwszy z tych typów występuje zdecydowanie rzadziej. W przypadku badanych organizacji pożytku publicznego sposób realizacji celów statutowych obejmuje przede wszystkim rozbudowany system opieki, koncentrujący się na dostarczaniu potrzebującym przedmiotów codziennego użytku, artykułów sanitarnych i higienicznych, odzieży oraz na udzielaniu wsparcia prawnego, mieszkaniowego, medycznego, szkoleniowego. Organizacje tworzą i realizują różnego typu programy mające na celu pomoc osobom i rodzinom w trudnej sytuacji życiowej poprzez m.in. organizowanie grup wsparcia i pomocy, w tym pomocy psychologiczno-pedagogicznej, a także działania integracyjne i reintegracyjne. Dzięki pracy wychowawczo-adaptacyjnej i socjoterapeutycznej rozwijane są zainteresowania i zdolności podopiecznych, eliminowane zaburzenia utrudniające relacje międzyludzkie, organizowany jest czas wolny i wypoczynek, uzupełniane braki wychowawcze, kształtowane właściwe postawy i wartości. Organizacje prowadzą punkty informacyjne, poradnictwo z udziałem specjalistów z różnych dziedzin, a także podejmują interwencje.

Organizacje pożytku publicznego chcące realizować swe cele w obszarze zdrowia i jego ochrony decydują się między innymi na inicjowanie i organizowanie badań przesiewowych i profilaktycznych, realizowanie programów prozdrowotnych, tworzenie i usprawnianie systemu opieki nad pacjentami podczas leczenia oraz po jego zakończeniu, poszukiwanie systemów rehabilitacji psychicznej i fizycznej, udzielanie pomocy placówkom medycznym i szpitalom.

Prowadzenie działalności edukacyjnej i kulturalnej polega w głównej mierze na organizowaniu wykładów, konferencji, seminariów, sympozjów, warsztatów, kursów, szkoleń, kampanii informacyjnych i programów społecznych, podczas których propagowana jest wiedza mogąca przyczynić się do poprawy życia osób potrzebujących, a także podniesienia świadomości społecznej w zakresie przysługujących praw obywatelskich i społecznych. W czasie tych spotkań słuchacze są szkoleni między innymi z psychologii i prawa, z których to dziedzin wiedza może przyczynić się do rozwiązywania takich problemów, jak wykluczenie społeczne 
i przemoc, oraz zachęcani do czynnej turystyki i rekreacji. Organizacje, promując aktywizację zawodową, oferują wsparcie z zakresu podnoszenia kwalifikacji zawodowych. Dzięki organizacji i finansowaniu imprez kulturalnych, artystycznych, towarzyskich i wypoczynkowych ich uczestnicy mają szansę na integrację. Upowszechnianie wiedzy realizowane jest także poprzez działalność informacyjną i wydawniczą polegającą na wydawaniu broszur, ulotek, plakatów, książek oraz prowadzeniu portali internetowych i kontakcie z mediami masowymi.

Część badanych organizacji pożytku publicznego decyduje się także na utworzenie, urządzenie i prowadzanie różnego typu instytucji, takich jak: poradnie małżeńskie, domy samotnych matek, szkoły dla rodziców, stołówki, noclegownie, placówki opiekuńczo-wychowawcze, świetlice, ośrodki terapeutyczno-rehabilitacyjne, punkty konsultacyjne i informacyjne, Uniwersytet Trzeciego Wieku. Organizacje te promują także i organizują wolontariat.

Aby skutecznie zrealizować cele statutowe, część organizacji nawiązuje i podtrzymuje współpracę z różnego typu instytucjami i organizacjami. Tworzone w ten sposób struktury i sieci opierają się między innymi na współtworzeniu programów zdrowotnych i społecznych, wzajemnym czerpaniu z wiedzy i doświadczenia, a także na współpracy finansowej i pozafinansowej. Organizacje, pragnąc uzyskać środki na realizację celów statutowych, występują o zlecanie zadań, dotacje, refundacje i inne środki publiczne. Aby gromadzić środki finansowe, organizowane są także imprezy i akcje charytatywne oraz zbiórki publiczne. Otrzymane wsparcie finansowe część organizacji przekazuje dalej, m.in. dla poszkodowanych kobiet i dzieci oraz w formie stypendiów, a także na finansowanie prowadzonych instytucji, takich jak schronienia i ośrodki opieki.

Kolejną formą spełniania celów statutowych jest występowanie do organów administracji rządowej i samorządu terytorialnego z wnioskami dotyczącymi rozwiązywania problemów dotyczących kobiet i rodziny oraz reprezentowanie i rzecznictwo interesów, np. grup mniejszościowych i dyskryminowanych. Organizacje zajmują się monitorowaniem problemów i zjawisk społecznych, w tym przestrzegania praw kobiet. Lobbują na rzecz równouprawnienia oraz ochrony praw kobiet, mając na uwadze realizację ich potrzeb.

\subsection{Sfery nieodpłatnych działań pożytku publicznego OPP działających na rzecz kobiet}

Cele statutowe i sposoby ich realizacji pokrywają się z deklaracjami badanych organizacji pożytku publicznego dotyczącymi sfer prowadzonych nieodpłatnych działalności pożytku publicznego (Rysunek 3). Sfery działalności pożytku publicznego są wskazywane bezpośrednio w sprawozdaniach przez organizację. Każda organizacja ma prawo wskazać trzy sfery nieodpłatnych działań. Badane organizacje wskazywały średnio 1,8 sfery $^{8}$. Zdarzało się, że jedna sfe-

\footnotetext{
${ }^{8}$ Było kilka organizacji, które wpisały trzy razy ten sam obszar.
} 
ra była wskazywana przez organizacje więcej niż jeden raz, a ta wielokrotność była wliczana do średniej procentowej. Sfery działań pożytku publicznego organizacje pozarządowe wskazują zgodnie z Ustawą z dnia 24 kwietnia 2003 r. o działalności pożytku publicznego i o wolontariacie (Dz.U. 2003, nr 96, poz. 873, z późń. zm.), w której to termin ten jest używany jako „sfera zadań publicznych".

Zgodnie z obszarami pożytku publicznego, najwięcej organizacji, bo $40 \%$, zajmuje się ochroną i promocją zdrowia. Działalność na rzecz osób niepełnosprawnych prowadzi ok. $31 \%$. Z kolei $20 \%$ badanych organizacji działa w sferze pomocy społecznej, w tym pomaga rodzinom i osobom w trudnej sytuacji życiowej oraz wyrównuje szanse tych rodzin i osób. Ponad 10\% deklaruje prowadzenie działalności na rzecz równych praw kobiet i mężczyzn, a niecałe $10 \%$ - działalności charytatywnej. Około 7\% zajmuje się sferą kultury, sztuki, ochrony dóbr kultury i dziedzictwa narodowego, a ponad 5\% wspiera i upowszechnia kulturę fizyczną, prowadzi działalność na rzecz osób w wieku emerytalnym i na rzecz integracji europejskiej; te 5\% zajmuje się też rozwijaniem kontaktów i współpracy między społeczeństwami oraz przeciwdziała uzależnieniom i patologiom społecznym (Rysunek 3).

Sfery nieodpłatnych działań

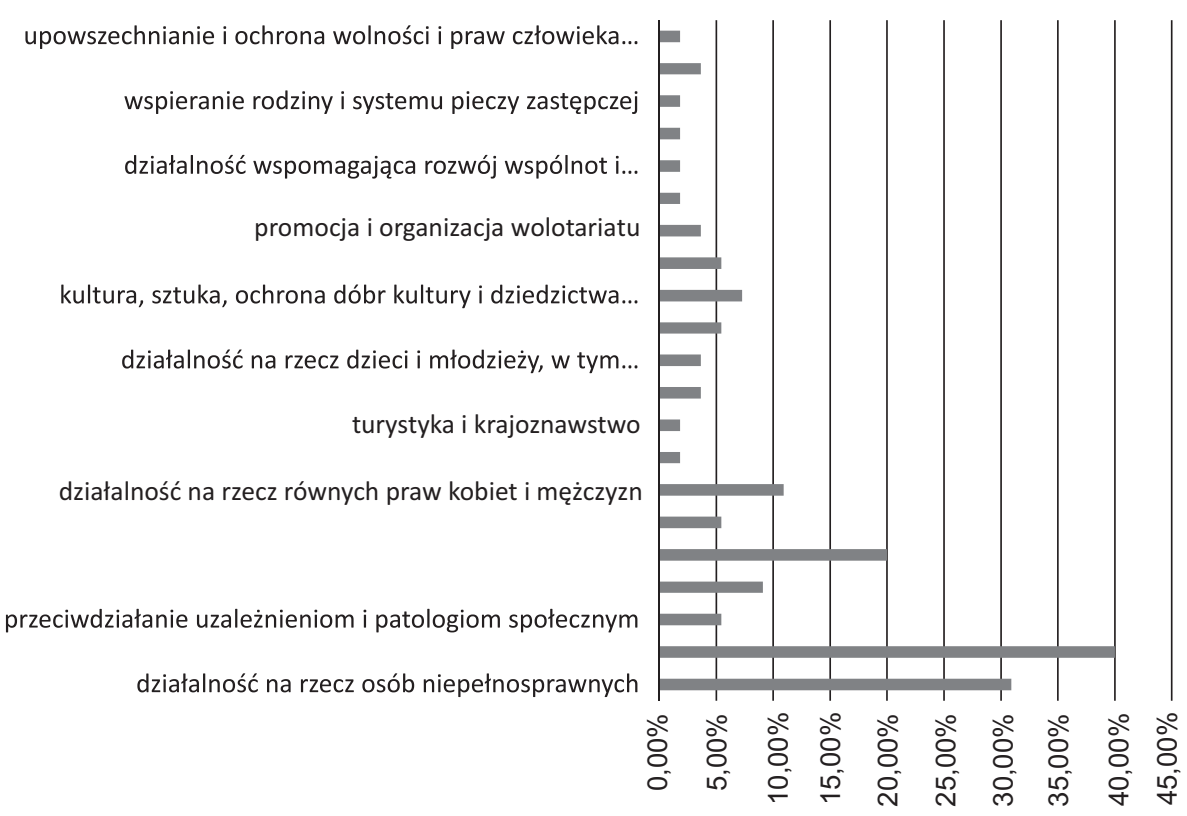

Rysunek 3. Sfery działalności pożytku publicznego w działalności nieodpłatnej badanych organizacji pożytku publicznego

Źródło: opracowanie własne na podstawie 55 wskazań w wypełnionych sprawozdaniach merytorycznych za 2015 rok na 55 badanych organizacji pożytku publicznego. 


\section{Wnioski}

Na podstawie przeprowadzonych badań można sformułować kilka najważniejszych wniosków, prezentujących aktywność kobiet w organizacjach pożytku publicznego zajmujących się potrzebami i oczekiwaniami środowiska kobiecego:

1. Udział kobiet we władzach organizacyjnych kobiecych OPP jest zdecydowanie dominujący. Jedynie niewielki odsetek mężczyzn zasiada w zarządach i organach kontroli lub nadzoru organizacyjnego, decydując się na pracę na rzecz kobiet i środowiska kobiecego. Podobnie wygląda sytuacja stanowisk prezesek i przewodniczących. Kobiece organizacje pożytku publicznego sytuują się więc odmiennie niż ogół polskich organizacji pozarządowych [Adamiak, Herbst, Przewłocka, 2012]: tam w zarządach częściej zasiadają mężczyźni. Należy jednakże zauważyć stosunkowo słabą reprezentację mężczyzn w organizacjach typowo kobiecych.

2. Obszary realizacji celów statutowych są zróżnicowane, najczęściej jednak mieszczą się w zakresie: prawa kobiet i ich realizacja, rozwój społeczno-ekonomiczny i integracja kobiet, pomoc społeczna, ochrona zdrowia, edukacja, kultura, sztuka i rekreacja, społeczeństwo obywatelskie. Zarówno cele, jak i sposoby ich realizacji często opracowywane są z myślą o kobietach, dzieciach i młodzieży. W różnych przypadkach jednak, kiedy organizacje deklarują cele związane np. z pomocą społeczną i prawem, wskazując odbiorcę swych działań, nie określają płci - tym samym w założeniu przeciwdziałają np. wykluczeniu społecznemu wszystkich osób na nie narażonych. Warto jednak zauważyć, że realizacja celów w przypadku obszaru zdrowia i jego ochrony często jest skierowana stricte na dotknięte chorobami kobiety (najczęściej są to tzw. choroby „kobiece”).

3. Warto zauważyć, że w dokumentach zapisane cele i sposoby ich realizacji są niezwykle bezpieczne, rzadko dotykają spraw kontrowersyjnych, zwłaszcza w zakresie kwestii feministycznych czy gender. Kobiece OPP dotyka ta sama przypadłość co większość polskich organizacji pozarządowych - szerokie zakreślanie celów i obszarów działania.

4. Wskazane w sprawozdaniach merytorycznych sfery nieodpłatnych działań pożytku publicznego jednoznacznie wskazują, że najwięcej badanych OPP zajmuje się ochroną i promocją zdrowia, pomocą osobom niepełnosprawnym i ogólnie pomocą społeczną. Rzadziej natomiast kobiece OPP odnoszą się do kwestii równościowych praw kobiet i mężczyzn.

5. Badania kobiecych OPP wyraźnie dowodzą więc, że istnieje potrzeba zarówno wzmacniania funkcji rzeczniczej $\mathrm{w}$ organizacjach pozarządowych, których cele są związane z rozwiązywaniem różnorodnych problemów kobiet w Polsce, oraz takich działań organizacji, których celem jest rozwiązywanie problemów kobiet, zwłaszcza kwestii związanych ze stereotypami płci czy segregacją poziomą i pionową w organizacjach (nie tylko pozarządowych), ale też wspieranie przedsiębiorczości społecznej kobiet. 
Na zakończenie należy podkreślić, że przeprowadzone badanie ma pewne ograniczenia. Po pierwsze, próba nie obejmuje wszystkich organizacji pożytku publicznego zajmujących się sprawami kobiet, lecz tylko te, które kwestie kobiece przywołują lub podkreślają w swojej nazwie. Po drugie, jakość badanych sprawozdań merytorycznych jest niska-zwłaszcza w zakresie celów i sposobów działania. Po trzecie, analizowano dokumenty tylko z ostatniego dostępnego roku sprawozdawczego (2015). W związku z tym badania należy traktować jako pewną ilustrację badawczą i wstęp do szerszych analiz w zakresie aktywności kobiecych organizacji pozarządowych w Polsce.

\section{Bibliografia}

Adamiak P., Charycka B., Gumkowska M. (2016), Kondycja sektora organizacji pozarzadowych $w$ Polsce 2015. Raport z badań, Stowarzyszenie Klon/Jawor, Warszawa.

Adamiak P., Herbst J., Przewłocka J. (2012), Podstawowe fakty o organizacjach pozarzadowych. Raport z badania 2012, Stowarzyszenie Klon/Jawor, Warszawa.

Baines D., Charlesworth S., Cunnigham I., Dassinger J. (2012), Self-monitoring, self-blaming, self-sacrificing workers: Gendered managerialism in the non-profit sector, „Womens's Studies International Forum", No. 35, s. 362-371.

Bogacz-Wojtanowska E., Rymsza M. (2009), Wzory zatrudnienia w trzecim sektorze. Wnioski i rekomendacje [w:] E. Bogacz-Wojtanowska, M. Rymsza (red.), Nie tylko społecznie. Zatrudnienie $i$ wolontariat $w$ trzecim sektorze, ISP, Warszawa.

Borowska M. (b.d.), Disscusion paper: Kobiety w sektorze pozarzadowym, ISP, Warszawa, [dok. elektr.] http://www.isp.org.pl/uploads/filemanager/kobietywtrzecimsektorze2.pdf [dostęp: 02.03.2017].

Borowska M. (2012), Równość szans kobiet i mężczyzn w sektorze pozarządowym. Diagnoza i rekomendacje, Instytut Spraw Publicznych, Warszawa.

Davidson E. (b.d.), Report on: Women's Philanthropy in the United States Trends and Developments, artykuł niepublikowany, The City University of New York, http:// www.philanthropy.org/publications/online_publications/women_paper.pdf [dostęp: 02.06.2017].

Domaradzka A. (2009), Kobiecy trzeci sektor [w:] Raport. Kobiety dla Polski. Polska dla kobiet. 20 lat transformacji 1989-2009, Fundacja Feminoteka, Warszawa.

Drewniak E. (2012), Wpływ kobiet na politykę państwa na przykładzie Polski i Hiszpanii, Wydawnictwo Promotor, Kraków.

Fondas N. (1997), Feminization Unveiled: Management Qualities in Contemporary Writings, „The Academy of Management Review”, Vol. 22, Issue 1, s. 257-282.

Kobiety w życiu publicznym (2013), CBOS, Warszawa.

Lanfranchi J., Narcy M. (2013), Female Overrepresentation in Public and Nonprofit Sector Jobs. Evidence From a French National Survey, ,Nonprofit and Voluntary Sector Quarterly", Vol. 44, No. 1, s. 47-74.

Mannon S.E., Petrzelka P. (2006), Keepin' this little town going, Gender and Volunteerism in Rural America, „Gender \& Society”, Vol. 20, No. 2, s. 236-258. 
Mendes S. (2007), Ruchy społeczne w Polsce [w:] M. Marody (red.), Wymiary życia społecznego. Polska na przełomie XX i XXI wieku, Wydawnictwo Naukowe Scholar, Warszawa, s. 439-469.

Morino M. (2011), Leap of Reason. Managing to Outcomes in an Era of Scarcity, A Venture Philanthropy Partners Publication, Washington.

Rozporządzenie Parlamentu Europejskiego i Rady UE nr 1303/2013 z dnia 17 grudnia 2013 r. ustanawiające wspólne przepisy dotyczące Europejskiego Funduszu Rozwoju Regionalnego, Europejskiego Funduszu Społecznego, Funduszu Spójności, Europejskiego Funduszu Rolnego na rzecz Rozwoju Obszarów Wiejskich oraz Europejskiego Funduszu Morskiego i Rybackiego oraz ustanawiające przepisy ogólne dotyczące Europejskiego Funduszu Rozwoju Regionalnego, Europejskiego Funduszu Społecznego, Funduszu Spójności i Europejskiego Funduszu Morskiego i Rybackiego oraz uchylające Rozporządzenie Rady UE nr 1083/2006.

Sahasrabuddhe M. (2013), http://www.quora.com/Why-do-more-women-work-in-the-non-profit-sector-than-men-and-does-this-mean-they-care-more-about-social-causes-than-men-do [dostęp: 01.03.2017].

Sköndalsinstitutet T.L., Wijkström F. (1995), Defining The Nonprofit Sector: Sweden Working Papers of the Johns Hopkins Comparative Nonprofit Sector Project, Stockholm School of Economics, Stockholm.

Vasavada T. (2012), A Cultural Feminism Perspective on Leadership in Nonprofit Organizations: A Case of Woman in India, „Public Administration Quarterly”, Vol. 36, No. 4.

Wartości i normy (2013), CBOS, Warszawa.

Wysocka T. (2009), Elastyczne formy zatrudnienia kobiet $w$ organizacjach pozarzadowych w świetle wyników badań [w:] E. Bogacz-Wojtanowska, M. Rymsza (red.), Nie tylko spotecznie. Zatrudnienie $i$ wolontariat w trzecim sektorze, ISP, Warszawa, s. 105-120.

Zaangażowanie społeczne Polek i Polaków. Wolontariat, filantropia, 1\% i wizerunek organizacji pozarzadowych. Raport z badania 2013 (2014), Stowarzyszenie Klon/Jawor, Warszawa.

www.pozytek.gov.pl [dostęp: 01.03.2017]. 